\title{
The Physical and Optical Societies Exhibition.
}

THE Physical and Optical Societies held their eleventh annual exhibition of scientific apparatus at South Kensington on January 5-6. There was a record attendance. The demonstrations and discourses were unusually attractive, a considerable number of visitors failing in their attempts to attend the discourses because of the overcrowded condition of the large lecture theatre. Sir W. H. Bragg gave an interesting lecture on "Sounds in Nature," and Mr. C. R. Darling showed by means of beautiful experiments some little-known surface-tension phenomena. On behalf of Prof. Archibald Barr, Dr. Morrison gave two addresses on the optophone, the instrument exhibited being the result of much patient research and development work by Messrs. Barr and Stroud. In the optophone a selenium bridge is exposed to successions of sets of light pulsations, which vary according to the forms of letters as these are passed over in traversing a line of printed type, each letter being indicated in a suitably connected telephone by a characteristic succession of single notes and chords. Printed letters are thus translated by the optophone into a sound alphabet which can be readily learned. Miss Mary Jameson, a blind girl, who attended the exhibition, read ordinary type at about ten words per minute, but when undisturbed her normal rate is about twenty-five words per minute. Many blind people were present.

Thermionic tubes and associated appliances were much in evidence. Prof. C. L. Fortescue and Dr. Bryan gave a very instructive demonstration of wellknown circuit arrangements having all the parts exposed to view. The "heterodyne" or "beat" method of reception was demonstrated, and surprised many visitors because of the clearness of the beat tone. Another demonstration involving the use of valves was given by Messrs. Creed and Co. The apparatus which was shown received and recorded wireless messages at a working speed of 200 words per minute. The record is a punched slip of paper which by means of a printer is transcribed into Roman characters. The research laboratories of the General Electric Co. exhibited a number of valves with a new type of filament. This filament runs at a much lower temperature than the ordinary tungsten filament in the valves in general use at present. The increased strength resulting from lower temperature permits the use of finer filaments, the watts for heating these being only one-twentieth to one-fortieth of usual values. Thus it is possible to work a six-valve amplifier with a current consumption of half an ampere. Characteristic curves for these valves are very similar to those for existing types in use for wireless telegraphy.

In the optics section, Mr. Aldis exhibited a com. paratively cheap but very perfect projector specially suited for projecting pond-life on the screen. With live specimens and a magnification of 300 , the alimentary canal and internal organs of many specimens were shown with great clearness. There should be a good future for this projector for educational purposes. Messrs. Adam Hilger demonstrated a little-known application of the Fabry-Perot interferometer. A beam of white light is caused to traverse successively two plates of air, each with silvered faces, a system of fringes being obtained whenever the differences of path occasioned by each of the plates bear to each other a simple relation. If, then, a Fabry-Perot étalon is placed in series with a FabryPerot interferometer (the air plate in the étalon having a constant thickness and in the interferometer a variable thickness) a system of white-light bands is produced every time the distance between the silvered surfaces of the interferometer mirrors is either a multiple or sub-multiple of the distance between the plates of the étalon. Messrs. Hilger also demonstrated the Zeeman effect with a wave-length spectrometer and a Lummer-Gehrcke parallel plate. Messrs. R. W. Paul and F. Twyman demonstrated by the use of a Hilger-type interferometer the distribution of temperature around a hot body. The convection currents produced in air by electrically heated wires were beautifully shown.

Cathode-ray workers were interested in a $12,000-v o l t$ direct-current generator set shown in operation by Messrs. Evershed and Vignoles. A cathode-ray tube was placed in circuit and some of the possibilities of the method of investigating rapid changes of current were demonstrated.

The general display of all exhibits was particularly good, and great credit is due to the forty-eight instrument-making firms who exhibited for the excellence of their manufactures and for the care taken in arranging and explaining the purposes of their instruments. The finish of electrical instruments was of a very high order-much higher than last year, when many mass-production instruments were shown. In many cases it was gratifying to find that elegance of production was accompanied by a surprising robust. ness. As an example a simple galvanometer which appeared to be very good for schools was shown by Messrs. Gambrell Bros.; this has a self-locking device when it is not supported on a table, and, in consequence, it withstands extraordinary shocks in transit. The Cambridge and Paul Instrument Co. showed for the first time a modification of the Einthoven string galvanometer having six strings, the deflections of which are recorded on a moving band of photographic paper. This type of galvanometer was first used in sound-ranging in France, and was of great service during the war. An excellent amplifier for cable work (but it should have many other applications) was exhibited by Mr. H. W. Sullivan; the amplifier is a selenium-cell relay which is acted upon by a light beam from a galvanometer; a magnification of 10,000 was obtained. As usual, the Weston Instrument Co. had an excellent display of meters and parts of meters which only required inspection for one to understand why a Weston instrument is always trustworthy.

The optical section of the exhibition attracted increased attention because of the position of the optical trade as a kev industry. The exhibits were certainly of a high class, and it is hoped that the efforts of the optical industry to establish itself firmly and to make its products inferior to none will receive support from the large number of visitors who admired the exhibits.

\section{The Headmasters' Association.}

THERE was a large muster at the annual meeting of the Association of Headmasters held in the Guildhall of the City of London on January 5. In his presidential address Mr. I. Talbot, headmaster of the Royal Grammar School, Newcastle-upon-Tyne, handled the new psychology in a sensible way No NO. 2672 , VOL. IO6] one can question the results of psycho-analysis when applied to cases of neurosis. Many a soldier owes his recovery from shell-shock to the skill of men like Dr. Rivers, Prof. Elliot Smith, and Prof. Pear. But when a smatterer who has merely "read a book," or perhaps only listened to a lecture, begins to fumble 